\title{
Adherence to Fluid Restriction and Quality of Life in Patients with Chronic Kidney Failure
}

\author{
Fajar Agung Nugroho ${ }^{1}$, Dewi Ayu Rahmawati ${ }^{2}$, Hendri Tamara Yuda Rahmadhani ${ }^{3}$ \\ \{fajar.18nugroho@gmail.com ${ }^{1}$ \} \\ Department of Adult Nursing, Student of Sekolah Tinggi Ilmu Kesehatan Muhammadiyah Gombong, \\ Central Java, Indonesia ${ }^{1,3}$ \\ Bachelor of Nursing, Student of Sekolah Tinggi Ilmu Kesehatan Muhammadiyah Gombong, Central \\ Java, Indonesia ${ }^{2}$
}

\begin{abstract}
Patients with chronic kidney disease should restrict the amount of liquid during their life. If they cannot control it, their body gets fluid overload and have harmful effects such as difficulty breathing and swelling. These problems can cause major changes in patients' lifestyle and their quality of life. Find out the relationship of adherence to fluid restriction and quality of life in patients with chronic kidney failure. This research used a descriptive correlation design with a Cross-Sectional approach. The sample of this study was 40 patients undergoing hemodialysis in PKU Muhammadiyah hospital of Gombong. It was conducted in March-April 2020. The respondents were selected by purposive sampling technique. Adherence to fluid restriction and quality of life questionnaire were used as research instruments. Data were analyzed descriptively using the Spearman rank test. Patients took control of fluid intake during the hemodialysis process in the adherence category $(67,5 \%)$. Patients had a good quality of life category $(65,0 \%)$. There was a significant relationship between adherence to fluid restriction with quality of life in patients with chronic kidney failure undergoing hemodialysis $(p=0.001)$. Further study expected can measure knowledge of patients with chronic kidney failure about how to do fluid restriction when undergoing hemodialysis and at their home.
\end{abstract}

Keywords: Adherence, Fluid restriction, Hemodialysis, Quality of life, Chronic kidney failure

\section{Introduction}

The kidneys are a vital human organ. Healthy kidneys have many important jobs like removing waste products and extra water from the body, controlling blood pressure, making red blood cells, and keeping bones healthy [1]. Kidney damage happens for more than three months, signed by structural or functional abnormalities of the kidney, with or without a decreased glomerular filtration rate [2].

The incidence and prevalence of patients with chronic kidney disease (CKD) are increasing worldwide. An article by Ellen (2020) confirmed that the global prevalence of Chronic Kidney Disease or CKD was 9.1\% (697.5 million cases) in 2017. Nearly one-third of CKD cases were in Asia countries like China (132.3 million) or India (115.1 million)[3]. Whereas the Consolidated Report on Indonesia Health Sector Review in 2018 reported by Gani dan Budiharsana that in 2017, there were 10.550 CKD cases and increased up to 11.660 in 2020[4]. 
Patients with CKD are necessary to have renal (kidney) replacement therapy with dialysis. Dialysis makes it possible for patients with CKD to live with the disease for many years [5]. Hemodialysis prevalence increases from year to year in Indonesia. In 2018 , the number increased to $2,754,409$ actions. The duration of the Hemodialysis procedure will take time for more than 4 hours [6]. The population of Chronic Kidney Failure in the age group $\geq 15$ years in the Central Java Province amounts to 96.794 [7].

Chronic Kidney Disease patients should be disciplined to dialytic procedures and fluid adherence restrictions [8]. Without the restriction of fluid, their physical will show oedema in around extremity parts. This condition makes the blood pressure increase and worsen the work of the heart, and pulmonary oedema causing the patient to get shortness of breath. Limiting fluid intake is essential so that CKD patients feel comfortable before, during and after hemodialysis therapy. This procedure was complicated for patients, especially if they are taking the drug such as diuretic. Because these drugs will cause thirst, which results in response to drinking [9].

Patients who undergo long-term hemodialysis have to face various problems, such as financial problems, difficulty in working, decreased sexual desire, depression and fear of dying, change their lifestyle, and spirit of life. QOL is an important parameter that needs to be addressed in chronic diseases like CKD. On the other hand, the energy of CKD patients has reduced strength, and it has affected parts of the quality of life (QOL) which includes physical health, psychological, spiritual, socioeconomic status and family dynamics [9]. The main objective of the study was to find out the relationship adherence to fluid restriction and quality of life in CKD patients at the Hemodialysis department.

\section{Method}

This cross-sectional study collected data by distributing a questionnaire to respondents. The respondents were CKD patients undergoing hemodialysis in PKU Muhammadiyah hospital of Gombong. A total of $40 \mathrm{CKD}$ patients on maintenance at least a year, they were selected using purposive sampling method. Inclusion criteria were age between 18- 65 years, durations of hemodialysis less than a year, and willing to participate in the study. CKD patients who were critically ill were excluded. They were recruited from March to April 2020. The data collection was started from March to April, 2020.

Sociodemographic information including age, gender, education, duration of illness, and duration on hemodialysis. To assess the patients' adherence to fluid restriction we used Adherence to fluid restriction questionnaire, an instrument developed by Hirmawaty (2014) [10]. It was divided into six dimensions: 1) Daily fluid intake; 2) Daily urine output; 3) Changes in body weight; 4) Nutrition; 5) Environment support. The items are graded in a Likert scale. While to evaluate the QOL of respondents was measured using WHOQOL-BREF questionnaire.

WHOQOL-BREF questionnaire consists of 26 items. Items 1 and 2 assess individual's overall perception of QOL and health, respectively; the remaining items are categorized under physical, psychological, social, and environmental domains. Each item is rated by a 5-point Likert scale. The responses were scaled in a positive direction. The mean score of the items within each domain was used to calculate the raw score. Raw scores were then transformed to a $0-100$ scale using a transformation formula. Higher score reflects a better QOL. WHOQOL- 
BREF questionnaire has been validated for assessing QOL in patients with CKD in different Settings and has been used to assess QOL by a number of studies elsewhere. We used sociodemographic data as predictor variables and all four domains, including items 1 and 2 , as outcome variables.

This research was approved by the Ethical Committee of Sekolah Tinggi Ilmu Kesehatan Muhammadiyah Gombong, Indonesia and it used guidelines from the Declaration of Helsinki. It was declared that there was no conflict of interest.

SPSS version 22.0 was used for the analysis of data. The data were analyzed using a quantitative approach including univariate analysis and bivariate analysis. The univariate analysis was to examine a description of the frequency distribution and bivariate analysis was performed to show whether there is a relationship between the dependent variables and independent variables performed using statistical testing procedures/ hypothesis, and it was evaluated using Spearman Rank test (a significance p-value of 0.05 and Confidence Interval or CI of $95 \%$. The test shows a significant relationship if the p-values are $<0.05$. Otherwise, it shows a non-significant relationship $>0.05$.

\section{Results and Discussion}

\subsection{Results}

\subsubsection{Sociodemographic: age, education, gender, and duration on hemodialysis}

Table 1 shows the sociodemographic: age, education, gender, and duration on hemodialysis by statistic descriptive.

Table 1. Sociodemographic: age, education, gender, and duration on hemodialysis

\begin{tabular}{llll}
\hline Characteristics & Category & f & \% \\
\hline \multirow{4}{*}{ Age } & Young adult & 4 & 10.0 \\
& Middle-aged adult & 23 & 57,5 \\
& Older adult & 13 & 32,5 \\
& Total & 40 & 100 \\
Education Level & Elementary & 15 & 37,5 \\
& Junior high school & 13 & 32,5 \\
\multirow{3}{*}{ Sex } & Senior high school & 9 & 22,5 \\
& Bachelor degree & 3 & 7,5 \\
& Total & 40 & 100 \\
Duration of & Female & 14 & 35,0 \\
hemodialysis & Male & 26 & 65,0 \\
& Total & 40 & 100,0 \\
& $\leq 6$ months & 17 & 42,5 \\
& $\geq 6$ months & 23 & 57,5 \\
& Total & 40 & 100 \\
\hline
\end{tabular}

Based on the Table 1, most of the respondents were in the category of middle-aged adult (57.5\%), elementary education (37.5\%), male $(65.0 \%)$, and duration on hemodialysis $\geq 6$ months (57.5\%). 


\subsubsection{Adherence to fluid restriction}

Based on the Table 2, it can be seen that most of the respondents who performed adherence in control the water intake, namely 27 respondents $(67.5 \%)$.

Table 2. Adherence to fluid restriction

\begin{tabular}{lll}
\hline Category & f & \% \\
\hline Non-Adherence & 13 & 32.5 \\
Adherence & 27 & 67.5 \\
\hline Total & 40 & 100.0 \\
\hline
\end{tabular}

\subsubsection{Quality of life of patients with chronic kidney failure}

Based on the Table 3, there were 26 respondents who had been in good quality of life ( 65.0 $\%)$, and 14 respondents were in low quality of life (35.0\%).

Table 3. Quality of life of patients with chronic kidney failure

\begin{tabular}{lll}
\hline Quality of Life & f & \% \\
\hline Poor & 14 & 35.0 \\
Low & 26 & 65.0 \\
\hline Total & 40 & 100.0 \\
\hline
\end{tabular}

3.1.4 Relationship between adherence to fluid restriction with quality of life of patients with chronic renal failure

Table 4 shows that most of the patients with chronic renal failure with adherence to fluid restriction were in adherence category and had a good quality of life.

Table 4. Relationship Between adherence to fluid restriction with quality of life of patients with Chronic Renal Failure

\begin{tabular}{lllll}
\hline & \multicolumn{2}{l}{ Quality of life } & & \\
\cline { 2 - 5 } Adherence level & Low & Good & \% & \% \\
\cline { 2 - 5 } & $\mathbf{N}$ & 76,9 & 3 & 23,1 \\
\hline Non-adherence & 10 & 14,8 & 23 & 85,2 \\
Adherence & 4 & 35,0 & 26 & 65,0 \\
\hline Total & 14 &
\end{tabular}

$r=0.516 ; \mathrm{p}: 0.001$

The results of the Spearman Rank test showed a correlation coefficient (r) 0,516, p $=0.001$ $(<0.05)$, it means that there was a relationship between adherence to fluid restriction to quality of life in patients with chronic kidney failure at Hemodialysis department in PKU Muhammadiyah Gombong Hospital. The correlation coefficient (r) showed a positive value that CKD patients who can be adherence to fluid restriction, they will have good quality of life. 


\subsection{Discussion}

\subsubsection{Adherence to fluid restriction}

The result data regarding respondent's adherence to fluid restriction showed that there were 27 respondents $(67.5 \%)$ were dominated in the adherence category. The reason why more than a half of the respondents was adherent because they got health education by nurses during undergoing hemodialysis treatment (pre, intra, and post). The nurses who were working at the hemodialysis department always conduct health education regarding fluid daily intake recommendation for CKD patients and measuring them before doing the treatment.

Definition of adherence is a person's behavior in taking medication, following dietary recommendations and making lifestyle changes by recommendations from health professionals [11]. Adherence or compliance is generally defined as the level of behavior of a person who receives medication, follows a diet and implements a lifestyle following the recommendations of health service providers according to WHO[11].

Chronic renal failure patients who do not comply with fluid intake restrictions will experience a buildup of fluid, causing pulmonary edema and hypertrophy in the left ventricle (Smeltzer \& Bare, 2013). The accumulation of fluids in the body causes the work function of the heart and lungs to get heavier, which results in the patient's physical response to fatigue and shortness of breath, physical activity also disrupted and moderate exercise (Riyanto, 2011).

Patients with chronic renal failure will undergo long-term hemodialysis treatment (HD). It is a procedure intended to remove body' waste products. This procedure was helped by a machine called a dialyzer. The frequency of HD treatment varies depending on the kidney function status, and the average patient gets it two-three times a week. At the same time, the duration of hemodialysis each treatment is at least three to four hours (Brunner and Suddath, 2013).

This research was in line with the study conducted by Nadia (2014) regarding the relationship between motivation and adherence of CKD patients with chronic kidney failure at the hemodialysis room in dr. Achmad Mochtar hospital of Bukit Tinggi (2014) that the respondents were in the adherence category (65.7\%). Sumigar's research (2015) showed that dietary adherence included fluid restriction is core management to maintain kidney function continuously with the principle of low protein and low salt, where patients must spend time undergoing the necessary treatment.

\subsubsection{Quality of life in for patients with chronic kidney failure}

The resulting study showed there were 26 respondents $(65.0 \%)$ in the good quality of life category. Quality of life for CHF patients undergoing hemodialysis therapy is a problem and needs the attention of health providers. Research by Kazama et al. (2019) showed that patients with chronic kidney disease (CKD) required more attention and knowledge related to supporting factors that can improve their QoL. Even though they were in the stage of terminal renal failure, the sufferers can live a long life with a reasonably good quality of life.

Quality of life definition is a patient's ability to enjoy normal life activities. It is an important consideration in medical care because some medical treatments can seriously impair life quality without appreciable benefit. In contrast, others greatly enhance their quality of life. Quality of 
life is not related to how long a person will live because it is not the human domain to determine it. To achieve the quality of life, it is necessary to fundamentally change the way patients perceive terminal renal failure $(\mathrm{CRF})$ itself.

New CKD patients tended to have higher anxiety and stress levels than old CKD patients with prolonged hemodialysis therapy. Patients undergoing hemodialysis therapy may experience impaired cognitive, adaptive, or social function compared to other normal people. The psychological problems experienced by patients who underwent hemodialysis therapy since the patient was diagnosed with chronic kidney failure. Feelings of loss of control, guilt, and frustration also play a role in the patient's emotional reactions. CKD disease makes patients feel helpless, realizing that the death of the body will make the patient feel very anxious and feel that his life is no longer meaningful so that the patient's quality of life decreases [12]. Other problems like financial, difficulty in keeping a job, lost sex drive, depression and fear of death. It will affect compliance with the restriction of fluid intake for CKD patients [13].

The cost of CKD treatment can be a burden for CKD patients. In Indonesia, this cost is expensive if they do not have health insurance to cover it. For a hemodialysis treatment was at least Rp. 700,000, it made obstacles for those who have limited budgets and do not have health insurance. CKD also made patients do not have a lot of activity at home, resulting in reduced physical health conditions [14].

The quality of life depends on the cultural norms and perceptions of the population. Quality of life-related to health Health-Related Quality of Life (HRQL) includes physical and mental limitations and positive expressions of physical, mental, and spiritual well-being. It can be used as an integrative measure that unifies mortality and morbidity and is an index as an element that includes mortality, morbidity, functional limitations, and being in good health [15].

CKD patients undergoing hemodialysis often report decreased quality of life. According to a study by Rahman et al. (2013) that CKD patients experienced a decrease in the patient's quality of life both physically, mentally, socially, and environmentally. The quality of life of CKD patients undergoing HD was attractive to health providers to explore and maintain its quality of life [16]. Lacson (2010) explained that CKD patients experienced a decrease in quality of life, including physical, mental, and social well-being [17]. The World Health Organization Quality of Life states that quality of life is an individual's perception of abilities, limitations, symptoms, and psychosocial characteristics of life in the context of culture and value systems to carry out their roles and functions [18]. Research conducted by Sathvik et al. (2008) in a healthcare unit in India using WHOQOL-Brief showed that the quality of life for healthy individuals or kidney transplants is much better than patients undergoing HD [19].

\subsubsection{Relationship between adherence to fluid restriction and quality of life in patients with chronic renal failure}

Results showed that most respondents were in the adherence category during the hemodialysis and good quality of life. For the patient with chronic kidney failure, proper nutrition, and adequate food are needed to provide a better quality of life. Inadequate nutrition is a significant predictor of death in hemodialysis patients [20], 2016). The chronic renal failure diet helps manage all types of food CKD patients, incredibly fluid intake.

Patients' ability to fluid intake restriction, nutrition status, medication adherence, and commitment undergo twice-weekly HD can improve the patient's quality of life. A study conducted by Black \& Hawks (2014), that hemodialysis management did not treat CKD but may slow the progression of the disease, help the kidney function, delaying the need for transplants as long as possible, eliminate waste products of the body, and providing quality of 
life optimal for the patient [21]. Albery \& Munafo (2011) said that adherence refers to a situation where an individual's behavior is equal with the action recommended or advice by a health practitioner or information obtained from some other health source of information. For instance, its adherence is that patients with chronic renal failure routinely undergo the recommended fluid intake restriction [22].

Adherence plays a vital role in sufferers of chronic disease to maintain patient survival. To achieve success in chronic disease management, individuals must be responsible for many aspects of their treatment on a regular and long-term. Patients need to incorporate lifestyle changes and other behavioral changes into their daily routine [23]. The psychological processes are required in adherence and non-adherence with a set of measures details to give the interventions which are designed to maximize the patients' society or benefit of patients from undergoing the treatment.

To overcome the severity and complications of chronic renal failure disease, a proper implementation and treatment are needed. Renal replacement therapy and a strict diet for chronic renal failure are the best treatments to avoid the worst possible or complications of chronic renal failure. The most common kidney replacement therapy in Indonesia are hemodialysis and dialysis therapy. In general, hemodialysis therapy and CKD diet therapy have several goals, such as, to keep nutrition status, maintain the patient's life and its well-being and provide optimal quality of life. [24].

Quality of life is a condition in which patients with their disease can feel physically, psychologically, socially and spiritually healthy, and optimally able to do activities and to be happy for themselves and others.[25]. The chronic renal failure diet is a diet setting recommended to limit consuming all types of food with specific aim. Therefore, most patients with chronic kidney failure should follow their diet program [26]. The results of this study were also consistent with a study about CKD diet that there was a significant relationship between folic acid consumption, low protein diet and vitamin B with good quality of life in patients with chronic kidney failure [27].

\section{Conclusion}

Patients with chronic renal failure at PKU Muhammadiyah Hospital of Gombong were in the adherence category into controlling fluid intake during the hemodialysis process $(67.5 \%)$ and having a good quality of life $(65.0 \%)$. There was a relationship between adherence to fluid restriction (intake) and quality of life in patients with chronic renal failure $(p=0.001)$.

\section{Acknowledgment}

We would like to thank Sekolah Tinggi Ilmu Kesehatan Muhammadiyah Gombong, Central Java, Indonesia for supporting their invaluable help in the preparation of this study. 


\section{References}

[1] Kidney Research UK, "The Kidneys - a Basic Guide," Kidney Heal. Inf., 2010, [Online]. Available: https://www.nhs.uk/Livewell/Kidneyhealth/Documents/kidney guide.pdf.

[2] J. R. Lukela, R. Van Harison, M. Jimbo, A. Mahallati, R. Saran, and Annie, "Management of Chronic Kidney Disease Key points," Michigan Med. Univ. Micihgan, no. July, 2019.

[3] C. Ellen F, "The impact of chronic kidney," Nat. Rev. Nephrol., vol. 16, no. May, p. 2020, 2020.

[4] A. Gani and M. P. Budiharsana, "The Consolidated Report on Indonesia Health Sector Review 2018," p. 56, 2018.

[5] P. S. Kent et al., "Academy of Nutrition and Dietetics and National Kidney Foundation: Revised 2014 Standards of Practice and Standards of Professional Performance for Registered Dietitian Nutritionists (Competent, Proficient, and Expert) in Nephrology Nutrition," J. Ren. Nutr., vol. 24, no. 5, pp. 275-285.e45, 2014, doi: 10.1053/j.jrn.2014.05.008.

[6] I. Registry, "11 th Report Of Indonesian Renal Registry 201811 th Report Of Indonesian Renal Registry 2018," pp. 1-46, 2018.

[7] K. Riskesdas, "Hasil Utama Riset Kesehata Dasar (RISKESDAS)," J. Phys. A Math. Theor., vol. 44, no. 8, pp. 1-200, 2018, doi: 10.1088/1751-8113/44/8/085201.

[8] R. A. Rettig, K. Norris, and A. R. Nissenson, "Chronic kidney disease in the United States: A public policy imperative," Clin. J. Am. Soc. Nephrol., vol. 3, no. 6, pp. 1902-1910, 2008, doi: 10.2215/CJN.02330508.

[9] B. and Suddart, Medical Surgical Nursing. 2010.

[10] T. Hirmawaty, "Pengaruh Metode Pendidikan Kesehatan Terhadap Kepatuhan Dalam Pembatasan Asupan Cairan Pada Pasien Gagal Ginjal Kronik di RSUD Tarakan," pp. 1-2, 2014, [Online]. Available: https://digilib.esaunggul.ac.id.

[11] T. O. Lo, "A D H E R E N C E TO LO N G - T E R M T H E R A P I E S World Health Organization 2003," 2003.

[12] P. Theofilou, "Noncompliance with Medical Regimen in Haemodialysis Treatment: A Case Study," Case Reports Nephrol., vol. 2011, pp. 1-4, 2011, doi: 10.1155/2011/476038.

[13] R. J. Muehrer, D. Schatell, B. Witten, R. Gangnon, B. N. Becker, and R. M. Hofmann, "Factors affecting employment at initiation of dialysis," Clin. J. Am. Soc. Nephrol., vol. 6, no. 3, pp. 489-496, 2011, doi: 10.2215/CJN.02550310.

[14] V. M. Nurani and S. Mariyanti, "Gambaran Makna Hidup Pasien Gagal Ginjal Kronik Yang Menjalani Hemodialisa," J. Psikol., vol. 11, no. 1, pp. 1-13, 2013, [Online]. Available: https://digilib.esaunggul.ac.id/public/UEU-Journal-4423-158-468-1-SM.pdf.

[15] M. L. U. Ritu K. Soni, Steven D. Weisbord, “Soni," Natl. Institue Heal., vol. 19, no. 2, pp. 153-159, 2011, doi: 10.1097/MNH.0b013e328335f939.Health-related.

[16] T. Rahman, R. C. Mittelhammer, and P. Wandschneider, "Measuring the Quality of Life across Countries A Sensitivity Analysis of Well-being Indices (Research Paper No. 2005/06)," Development, vol. 5, no. October 2014, pp. 1-32, 2005, [Online]. Available: http://www.econstor.eu/handle/10419/63384\%5Cnhttp://archive.unu.edu/hq/library/Collection/PDF files/WIDER/WRP/WRP065.pdf.

[17] E. Lacson, W. Wang, K. Lester, N. Ofsthun, J. M. Lazarus, and R. M. Hakim, "Outcomes associated with in-center nocturnal hemodialysis from a large multicenter program," Clin. J. Am. Soc. Nephrol., vol. 5, no. 2, pp. 220-226, 2010, doi: 10.2215/CJN.06070809.

[18] R. Skolnik and S. Heung, "W orld H ealth O rganization ( WHO )," Int. Encycl. Anthropol., pp. 13, 2018, doi: 10.1002/9781118924396.wbiea1496.

[19] A. Bestari, "Pengaruh Dukungan Keluarga Dan Status DM Terhadap Kualitas Hidup Pasien Hemodialisis," J. Berk. Epidemiol., vol. 4, no. December, pp. 200-212, 2016, doi: 10.20473/jbe.v4i2.2016.200.

[20] N. Kharisma Putri, J. Evy Tyaswati, and Santosa, "Hubungan antara Tingkat Depresi dengan Kualitas Hidup Pasien," e-Jurnal Pustaka Kesehat., vol. 4, no. 3, p. 459, 2016.

[21] D. R. Sulistyaningsih and R. Setyawati, "the Effectiveness of Efficacy Training Toward Quality of Life Patient' S Undergo Hemodialysis," 2010. 
[22] G. Y. Park and E. K. Yoo, "A study on quality of life in hemodialysis patients," Inf., vol. 19, no. 11, pp. 5607-5612, 2016, doi: 10.5455/msm.2015.27.305-309.

[23] 2013 Dien et al., "The Quality of Lifestyle and the Quality of Life Militza," Bone, vol. 23, no. 1, pp. 1-7, 2008, doi: 10.1001/archinternmed.2011.442.The.

[24] W. Wantonoro and A. Rahmawati, "Changes of Health Related Quality of Life Dimensions In Hemodialysis Patients," Media Keperawatan Indones., vol. 3, no. 3, p. 159, 2020, doi: 10.26714/mki.3.3.2020.159-165.

[25] P. B. Tarigan, "Faktor-Faktor Yang Mempengaruhi Kualitas Hidup Pasien Chronic Kidney Disease (Ckd) Yang Menjalani Hemodialisa," J. Chem. Inf. Model., vol. 53, no. 9, pp. 1689-1699, 2013.

[26] National Kidney Foundation, "Nutrition and Chronic Kidney Disease (Stages 1-4): are you getting what you need?," Natl. Kidney Found., pp. 1-28, 2015, [Online]. Available: http://www.kidney.org/atoz/pdf/nutri_chronic.pdf\%5Cnhttps://www.kidney.org/atoz/content/nutriki dfail_stage1-4.

[27] National Kidney Foundation., "Clinical Practice Guideline for Nutrition in Chronic Kidney Disease: 2019 Update,” Acad. Nutr. Diet., no. October, pp. 131-147, 2019. 